\title{
Modeling the behaviour of alluvial and blasted quarried rockfill materials
}

\author{
N. P. Honkanadavar • Nripendra Kumar • \\ Murari Ratnam
}

Received: 26 July 2013/ Accepted: 12 May 2014/Published online: 5 June 2014

(C) The Author(s) 2014. This article is published with open access at Springerlink.com

\begin{abstract}
Two types of modeled rockfill materials were collected from Renuka dam site, Himachal Pradesh, India and Salma dam site, Afghanistan. The rockfill material collected from Renuka dam site is rounded to sub-rounded in shape and the rockfill material collected from Salma dam site is angular to sub-angular in shape. The prototype gradation rockfill material consists maximum particle size larger than $1,000 \mathrm{~mm}$. Therefore, for carrying out laboratory testing and modeling the bahaviour, the prototype rockfill material is scaled down to the maximum particle size $\left(\mathrm{d}_{\max }\right)$ of 25,50 and $80 \mathrm{~mm}$ for both projects material using parallel gradation technique. Triaxial compression and Index properties tests were conducted on both project rockfill materials and are presented. From the triaxial behaviour, it is observed that the stress-strain behaviour is non-linear, inelastic and stress dependent for both the materials. The material compresses during the initial shearing and shows dilation effect with further shearing. It is observed that the $\phi$-value for alluvial rockfill material increases with increase in $d_{\max }$ and reverse trend is
\end{abstract}

N. P. Honkanadavar $(\bowtie) \cdot$ N. Kumar · M. Ratnam

Central Soil and Materials Research Station,

New Delhi 110016, India

e-mail: nphonkanadavar@gmail.com

N. Kumar

e-mail: nkmr_csmrs@rediffmail.com

M. Ratnam

e-mail: director-csmrs@nic.in observed for blasted quarried rockfill material which shows the importance of the type of material. The stress-strain-volume change behaviour of both projects modeled rockfill material was predicted by using hierarchical single surface (HISS) model based on elasto plasticity and compared with the laboratory test results. From the comparison, it is observed that both results match closely. It is, therefore, suggested that the behaviour of both types of rockfill materials can be characterized successfully using HISS model.

Keywords Rockfill · Modeling - Triaxial test · Stress-strain behaviour $\cdot$ HISS model

\section{Introduction}

Number of river valley projects are being planned and implemented in India and abroad to store the natural water flowing in the rivers and use it later for different purposes viz. power generation, irrigation and flood control etc. Concrete, Masonry and Earth and rockfill dams are being constructed to store the river water. However, now a days, rockfill dams are widely being constructed all over the world because of their inherent flexibility, capacity to absorb large seismic energy, adaptability to various foundation conditions and economical as well. The behaviour of the rockfill materials used in the earth and rockfill dam is of considerable importance for the analysis, safe and economical design of rockfill dams. The prototype 
rockfill material used in the dam construction is large in size and it is not feasible to test it directly in the laboratory. Therefore, some kind of modeling technique is often used to reduce the size of particles so that the specimens prepared with smaller size particles can be prepared and tested in the laboratory. Among all available modeling techniques, the parallel gradation technique (Lowe 1964) is most commonly used and the same has been adopted in the present study. The behaviour of the rockfill materials has been reported by number of researchers. Marsal (1967), Marachi et al. (1969), Venkatachalam (1993), Gupta (2000), and Abbas (2003), Honkanadavar (2010), Varadarajan et al. (1997, 1999, 2002, 2003, 2006), Honkanadavar (2011, 2012a, Honkanadavar et al. 2012) have performed laboratory tests on various rockfill materials with different confining pressures. They concluded that the strength parameter, $\phi$ varies with the particle size. They had also observed that the trend of behaviour of alluvial rockfill material is opposite to that of blasted quarried rockfill material. For blasted quarried rockfill materials the angle of internal friction, $\phi$ decreases with increase in $d_{\text {max }}$ and for alluvial rockfill material the angle of internal friction, $\phi$ increases with increase in $d_{\max }$. HISS models have been used successfully to model the behavior of various materials (Desai 2001; Desai et al. 1986, 1995a, 1995b, Desai and Ugai 1996; Desai and Varadarajan 1987; Varadarajan and Desai 1987, 1993; Najjar et al. 1994; Varadarajan et al. 1994, 1997, 1999, 2002a, 2002b, 2003, 2006; Gupta 2000; Abbas 2003; Honkanadavar 2010; Xiao et al. Xiao et al. 2011a, 2011b, 2012; Honkanadavar 2012). They predicted the stress-strain-volume change behaviour of materials and compared with the observed results. From the predicted and observed results they found that both observed and predicted results match closely.

In the present research work, two types rockfill materials (alluvial and blasted quarried) have been considered. Renuka dam is a $148 \mathrm{~m}$ high earth and rockfill dam constructed using alluvial rockfill material across river Giri in Himachal Pradesh, India and Salma dam is a $107.5 \mathrm{~m}$ high earth and rockfill dam constructed using quarried blasted rockfill material across river Hari Rud, Afghanistan. The rock type of alluvial rockfill is limestone and quarried blasted rockfill is metamorphic gneiss. The details of project, location and types of rock are
Table 1 Rockfill Materials Used

\begin{tabular}{|c|c|c|}
\hline $\begin{array}{l}\text { Project } \\
\text { name }\end{array}$ & Location & $\begin{array}{l}\text { Name of the } \\
\text { rock }\end{array}$ \\
\hline $\begin{array}{c}\text { Renuka } \\
\text { Dam }\end{array}$ & $\begin{array}{l}\text { Located on river Giri about } 375 \mathrm{~m} \\
\text { downstream of confluence of } \\
\text { Jogar-ka-Khala with river Giri in } \\
\text { Himachal Pradesh, India }\end{array}$ & Limestone \\
\hline $\begin{array}{r}\text { Salma } \\
\text { Dam }\end{array}$ & $\begin{array}{l}\text { Rock quarry near the Salma dam } \\
\text { site } 2 \mathrm{~km} \text { downstream of Salma } \\
\text { village in Herat province, } \\
\text { Afghanistan }\end{array}$ & $\begin{array}{l}\text { Metamorphic } \\
\text { gneiss }\end{array}$ \\
\hline
\end{tabular}

presented in Table 1. This paper deals with the laboratory study of stress-strain-volume change behaviour, determination of shear strength parameters, prediction of the behaviour for rockfil material using non-associative HISS constitutive model and comparison of laboratory and predicted behaviour of both projects rockfill materials.

\section{Experimental Investigations}

\subsection{Rockfill Materials Used}

In the present research work modeled alluvial and blasted modeled quarried rockfill materials from Renuka dam site, India and Salma dam site, Afghanistan are obtained and used for research work. The details of the materials, location and rock types are given in Table 1 . The alluvial rockfill material consist of rounded to sub-rounded particles in shape and quarried blasted rockfill material consist of angular to sub-angular in shape. The particle shapes of modeled alluvial (Renuka dam site) and blasted modeled quarried rockfill (Salma dam site) materials are shown in Figs. 1 and 2 respectively. Laboratory tests were conducted to determine the index properties of both types of rockfill materials and are given in Table 2. Prototype gradation rockfill material consists of maximum particle sizes of 1,000 and $600 \mathrm{~mm}$ for Renuka dam and Salma dam respectively. Rockfill material with such a large particle size is not feasible to test in the laboratory. Among all the available modeling techniques, the parallel gradation technique (Lowe 1964) is most commonly used and the same has been adopted in the present study to model the 
Fig. 1 Modeled Alluvial Rockfill Materials from Renuka Dam project, Himachal Pradesh, India

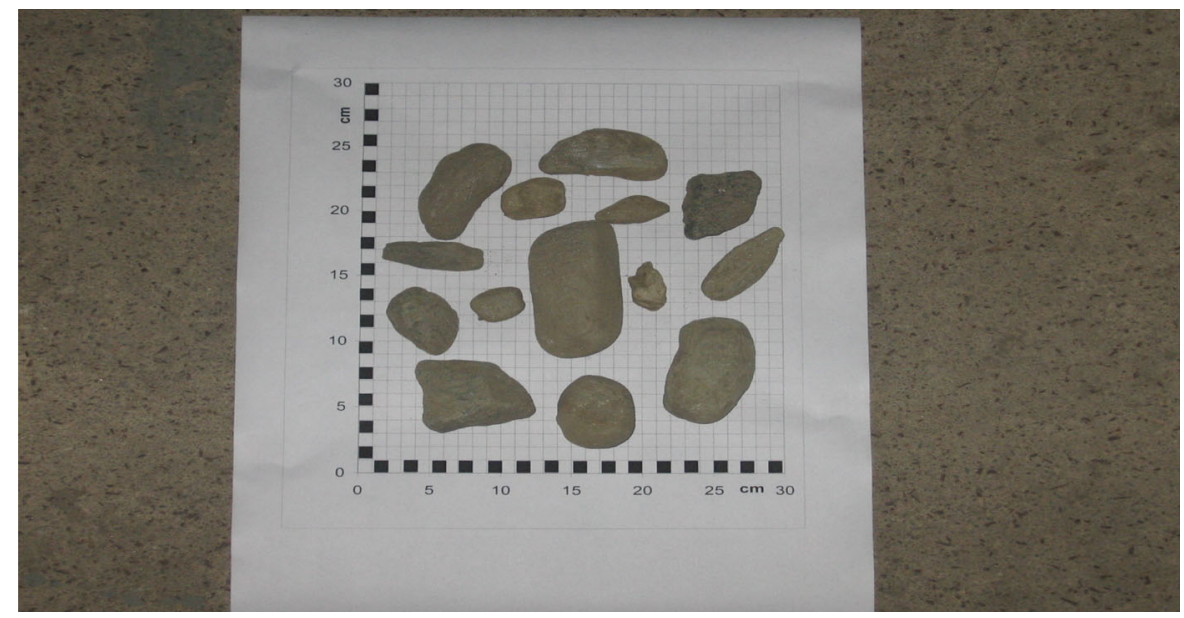

Fig. 2 Modeled Quarried Blasted Rockfill Materials from Salma Dam project, Afghanistan

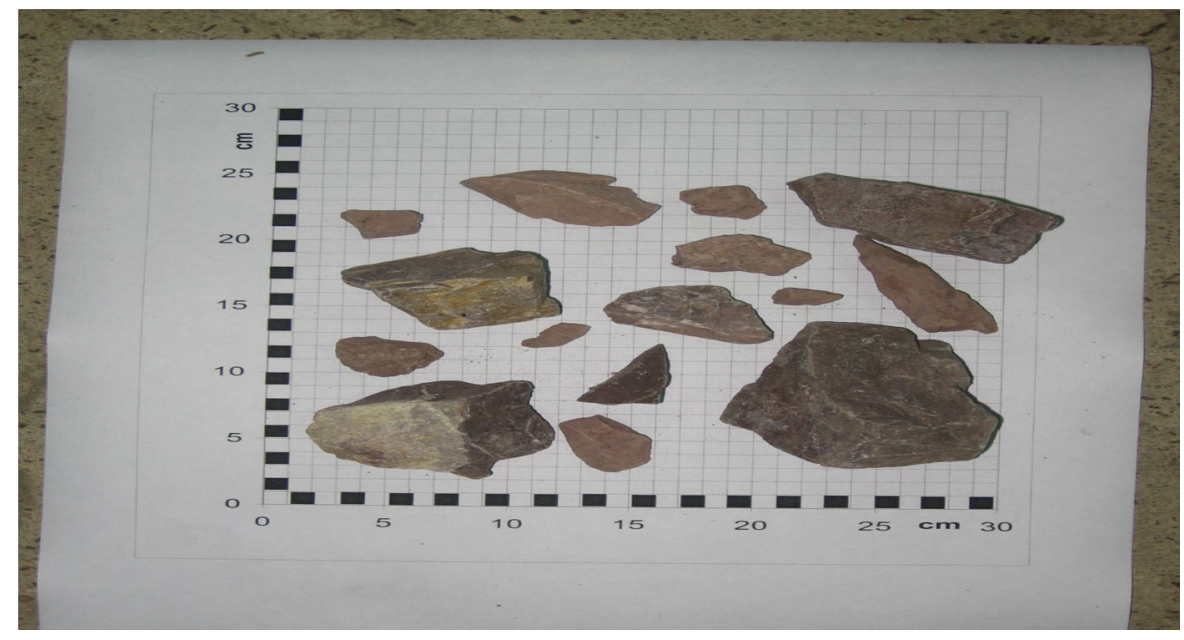

Table 2 Index Properties of both Alluvial and Quarried Blasted Rockfill Materials

\begin{tabular}{llll}
\hline $\begin{array}{l}\text { Sl. } \\
\text { No. }\end{array}$ & Name of the test & $\begin{array}{l}\text { Renuka Dam } \\
\text { project }\end{array}$ & $\begin{array}{l}\text { Salma Dam } \\
\text { project }\end{array}$ \\
\hline 1 & Los Angeles abrasion (\%) & 21.25 & 44.80 \\
2 & $\begin{array}{l}\text { Aggregate crushing } \\
\text { value (\%) }\end{array}$ & 35.20 & 38.90 \\
3 & $\begin{array}{l}\text { Aggregate impact } \\
\text { value (\%) }\end{array}$ & 26.90 & 34.90 \\
4 & Water absorption (\%) & 1.3 & 1.8 \\
5 & Specific gravity & 2.66 & 2.73 \\
\hline
\end{tabular}

prototype rockfill materials. Modeled rockfill materials with $\mathrm{d}_{\max }$ of 80,50 and $25 \mathrm{~mm}$ for Renuka and Salma dam projects were obtained using parallel gradation technique. The prototype and modeled gradation curves for Renuka and Salma dam rockfill materials are shown in Figs. 3 and 4 respectively.

The values of index properties of alluvial rockfill material shows lessor values as compared to blasted quarried rockfill materials. This is due to the reason that the alluvial rockfill material formed as a result of disintegration of the hill rock in the upper himalaya, carried away the same by water, impact, rolling, sliding action in the riverbed and depositing the only hard core portion of the rock particles. However, the blasted rock is fresh, angular, having minor cracks and loose surface corners gives the index values higher as copmpared to alluvial rockfill material. As these values of both projects material are within the permissible limit, both materials can be used as rockfill material in the construction of rockfill dam. 


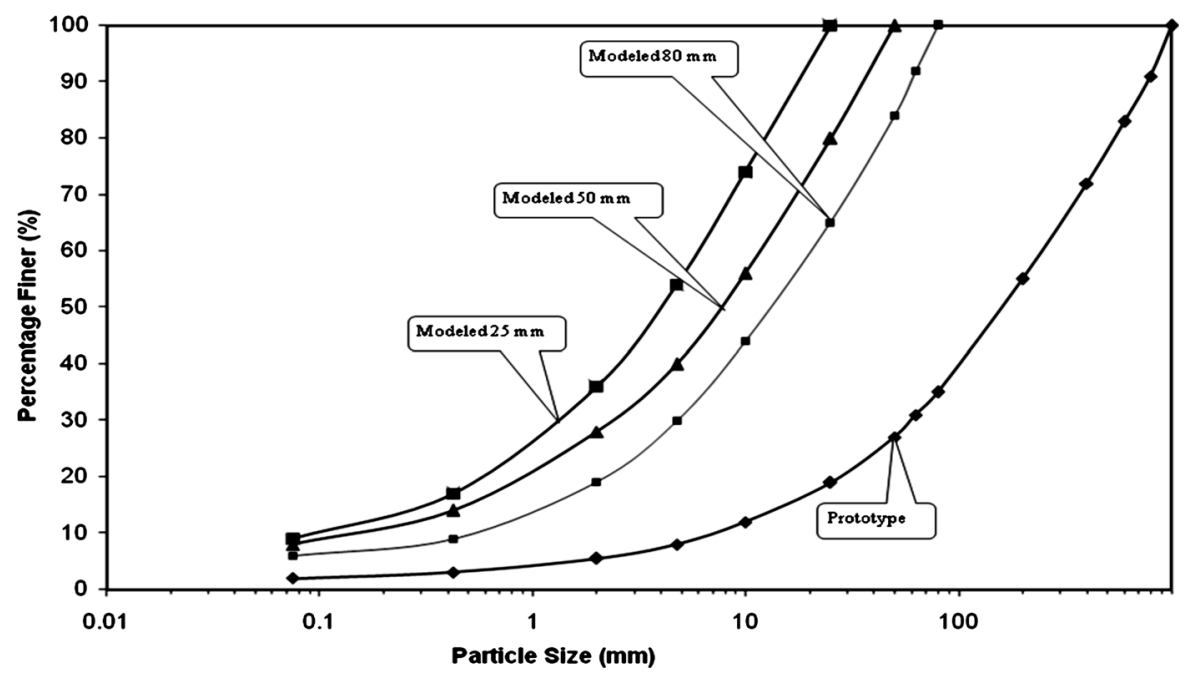

Fig. 3 Prototype and Modeled Grain Size Distribution Curves for Renuka Dam Project

Fig. 4 Prototype and Modeled Grain Size Distribution Curves for Salma Dam Project

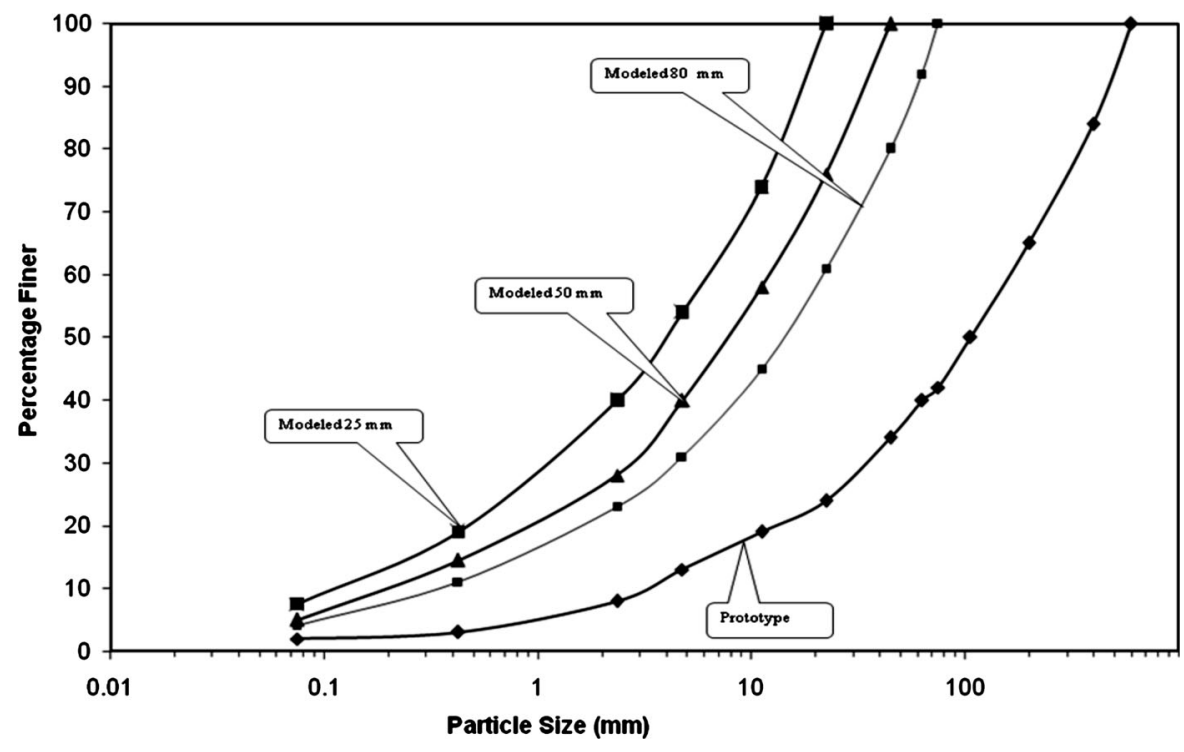

\subsection{Experimental Programme}

\subsubsection{Drained Triaxial Shear Tests}

Relative density tests were conducted and determined minimum and maximum dry densities for both projects modeled rockfill material. Using minimum and maximum dry densities, the packing density of the specimen for triaxial shear test was determined corresponding to $87 \%$ relative density. A specimen size of $381 \mathrm{~mm}$ diameter and $813 \mathrm{~mm}$ height is prepared and consolidated drained triaxial shear tests have been conducted on all the modeled rockfill materials collected from both the projects. Details of the triaxial equipment used in the present research work are given in Fig. 5. For testing, a dry density corresponding to $87 \%$ relative density is adopted. Three confining pressures i.e. $0.4,0.8$ and $1.2 \mathrm{MPa}$ were used for testing each $d_{\max }$ of modeled rockfill material. The quantities of various fractions of modeled rockfill materials required to achieve the gradation for preparing the specimen at the specified density was determined by weight. The specimen was prepared using a split mould and two rubber 
Fig. 5 Triaxial Compression Test Setup (381 $\mathrm{mm}$ dia. and $813 \mathrm{~mm}$ high)

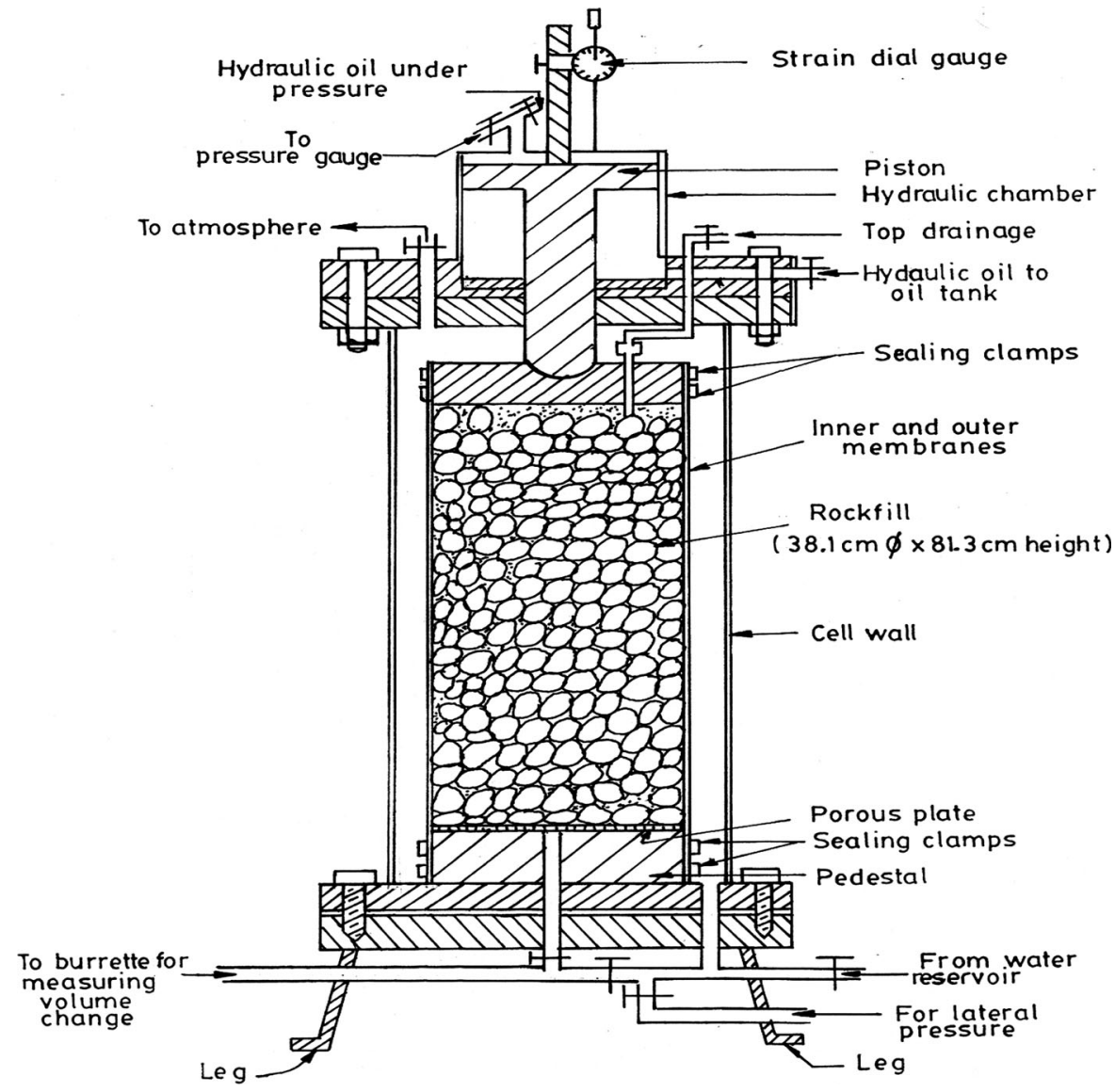

membranes of $1 \mathrm{~mm}$ inner and $3 \mathrm{~mm}$ outer. The specimen was compacted in six equal layers using mechanical vibratory compactor. The specimen was saturated by allowing water to pass through the base of the triaxial specimen and using a top drainage system for removing air voids. Conventional triaxial compression (CTC) tests were conducted in two phases; consolidation and shearing. In the first phase, required consolidation pressure is applied to the specimen and recorded the change in the volume of the specimen by allowing the water to drain out. In the second phase, keeping the confining pressure constant, the specimen was sheared till the failure under strain controlled test with a rate of loading $1 \mathrm{~mm} / \mathrm{min}$. During the test, for every strain level, deviator stress and volume change is recorded. The specimen is considered as failed when the specimen stops taking the load or when axial strain reaches $15 \%$ whichever is earlier. From the test results, stress-strain-volume change behaviour was studied and presented.
2.2.1.1 Stress-Strain-Volume Change Behaviour The details of projects, maximum particle size $\left(\mathrm{d}_{\max }\right)$, confining pressure, $\sigma_{3}$, axial strain, $\varepsilon_{1}$ and volumetric strain $\varepsilon_{\mathrm{v}}$ at failure for peak deviator stress are presented in Table 3. Stress-strain-volume change behaviour of six modeled rockfill materials tested for three confining pressures viz. $0.4,0.8$ and $1.2 \mathrm{MPa}$ for Renuka dam and Salma dam projects are shown in Figs. 6, 7, 8, 9 and 10 and 11. From the deviator stress v/s axial strain relationship, it is observed that the behaviour of both materials is non-linear, inelastic and stress level dependent. For a $\mathrm{d}_{\max }$, the deviator stress and axial strain at failure increases with increase in confining pressure for both the materials. For a confining pressure, the deviator stress increases with increase in $d_{\max }$ for alluvial rockfill materials and it decreases with increase in $d_{\max }$ for quarried rockfill material. From the observed stress-strain curves of all the $\mathrm{d}_{\max }$ tested, it is observed that the kind of mode of failure of specimen is brittle shear failure. The volume 
Table 3 Axial and Volumetric Strains at Failure (Peak Deviator Stress) for Renuka Dam and Salma Dam Projects

\begin{tabular}{|c|c|c|c|c|}
\hline $\begin{array}{l}\text { Name of } \\
\text { project }\end{array}$ & $\begin{array}{l}\mathrm{d}_{\max } \\
(\mathrm{mm})\end{array}$ & $\begin{array}{l}\text { Confining } \\
\text { pressure } \\
\left(\sigma_{3}\right) \mathrm{MPa}\end{array}$ & $\begin{array}{l}\text { Axial } \\
\text { strain at } \\
\text { failure }(\%)\end{array}$ & $\begin{array}{l}\text { Volumetric } \\
\text { strain at } \\
\text { failure }(\%)\end{array}$ \\
\hline \multirow{9}{*}{$\begin{array}{l}\text { Renuka } \\
\text { Dam } \\
\text { project }\end{array}$} & \multirow[t]{3}{*}{25} & 0.4 & 8.0 & 0.455 \\
\hline & & 0.8 & 8.5 & 1.060 \\
\hline & & 1.2 & 9.0 & 1.650 \\
\hline & \multirow[t]{3}{*}{50} & 0.4 & 8.5 & 0.526 \\
\hline & & 0.8 & 9.5 & 1.385 \\
\hline & & 1.2 & 10.0 & 1.831 \\
\hline & \multirow[t]{3}{*}{80} & 0.4 & 9.0 & 0.605 \\
\hline & & 0.8 & 10.0 & 1.465 \\
\hline & & 1.2 & 10.5 & 1.910 \\
\hline \multirow{9}{*}{$\begin{array}{l}\text { Salma } \\
\text { Dam } \\
\text { project }\end{array}$} & \multirow[t]{3}{*}{25} & 0.4 & 8.5 & 0.565 \\
\hline & & 0.8 & 9.0 & 1.213 \\
\hline & & 1.2 & 9.5 & 1.824 \\
\hline & \multirow[t]{3}{*}{50} & 0.4 & 9.0 & 0.662 \\
\hline & & 0.8 & 9.5 & 1.531 \\
\hline & & 1.2 & 10.0 & 1.985 \\
\hline & \multirow[t]{3}{*}{80} & 0.4 & 9.5 & 0.736 \\
\hline & & 0.8 & 10.0 & 1.625 \\
\hline & & 1.2 & 10.5 & 2.312 \\
\hline
\end{tabular}

change behaviour shows compression during the initial stage of shearing and dilation effect is observed with further shearing for all the $d_{\max }$. No strength reduction phenomenon or strain-softening behavior is observed when the stress state passes the

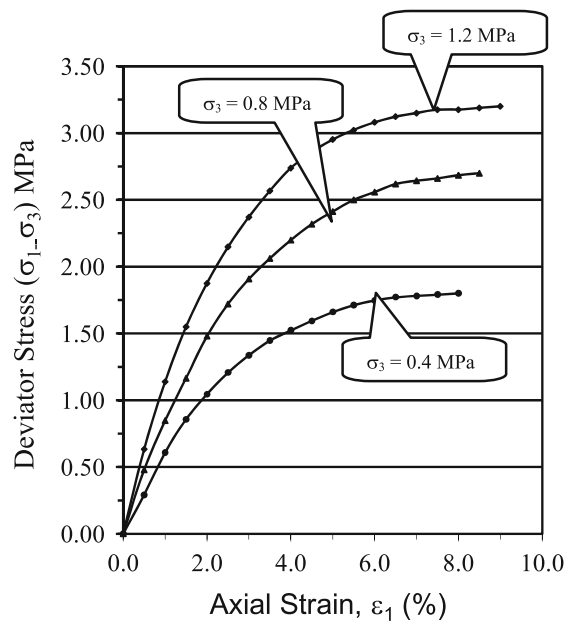

(a) phase changing line. The dilation effect decreases with increase in confining pressure and $\mathrm{d}_{\max }$ for both the materials. Similar behavior has been observed and reported by Varadarajan et al. (1997, 1999, 2002, 2003, Varadarajan and Abbas 2006); Honkanadavar (2010); Honkanadavar and Sharma (2011, 2012a); Honkanadavar et al. (2012b).

\subsubsection{Evaluation of Shear Strength Parame-} ters Mohr-Coulomb failure criterion has been adopted for determining the angle of internal friction at failure. Failure envelopes in mean stress $\left(\sigma_{\mathrm{m}}\right) \mathrm{v} / \mathrm{s}$ deviator stress $\left(\sigma_{1}-\sigma_{3}\right)$ space are plotted for all the $\mathrm{d}_{\max }$ tested with different confining pressures for Renuka and Salma dam materials. The angle of internal friction, $\phi$ is determined from the best fit straight lines of these plots for both the modeled rockfill materials. Figure 12 shows a typical plot for Renuka dam site alluvial modeled rockfill material for maximum particle size $\left(\mathrm{d}_{\max }\right)$ of $25 \mathrm{~mm}$. It is observed that the cohesion, $c$ for all the drained tests with a $d_{\max }$ of both project rockfill materials is observed as zero. The $\phi$-values are tabulated in Table 4.

\subsubsection{Effect of Particle Size on Strength Parameter, $\phi$}

The strength of rockfill material used in the construction of rockfill dams is affected by number of factors such as mineral composition, particle size, shape, gradation, relative density and surface texture of the

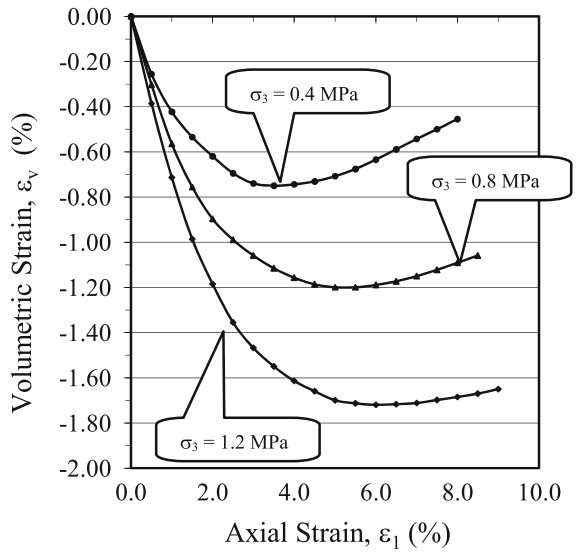

(b)

Fig. 6 Stress-Strain-Volume Change Behaviour of $25 \mathrm{~mm} \mathrm{~d}_{\max }$ for Renuka Dam Project Material. a Stress-strain behaviour b Volume change behaviour 


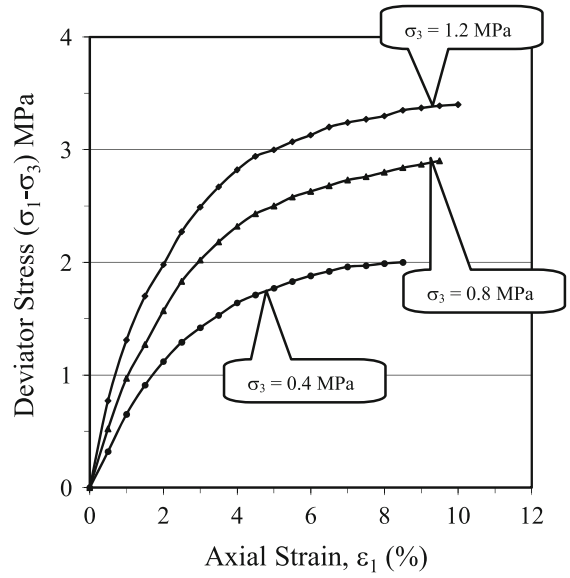

(a)

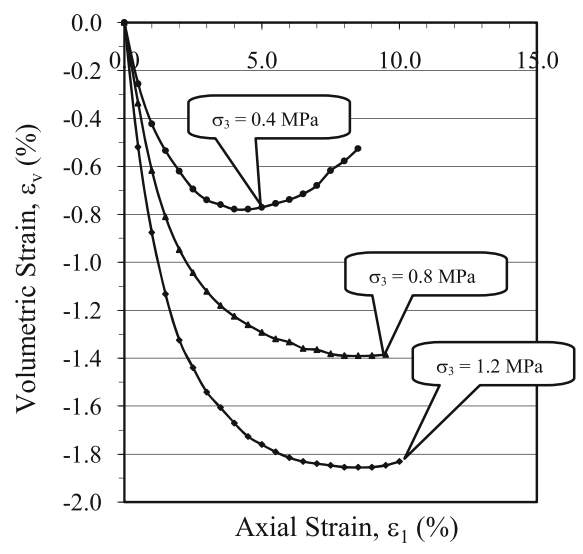

(b)

Fig. 7 Stress-Strain-Volume Change Behaviour of $50 \mathrm{~mm} \mathrm{~d}_{\max }$ for Renuka Dam Project Material. a Stress-strain behaviour b Volume change behaviour

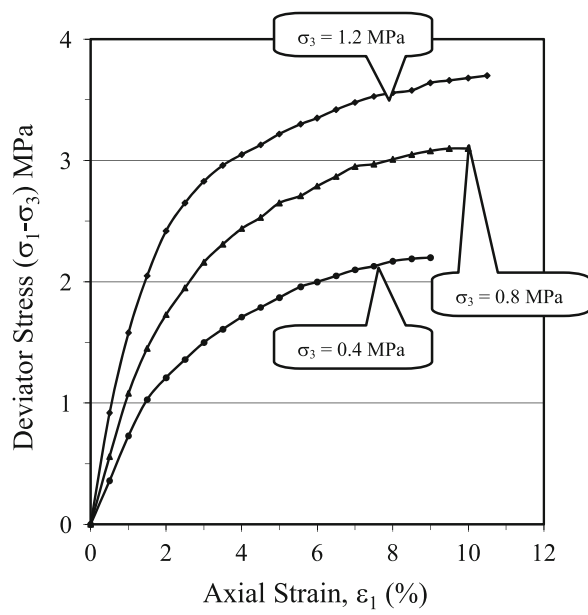

(a)

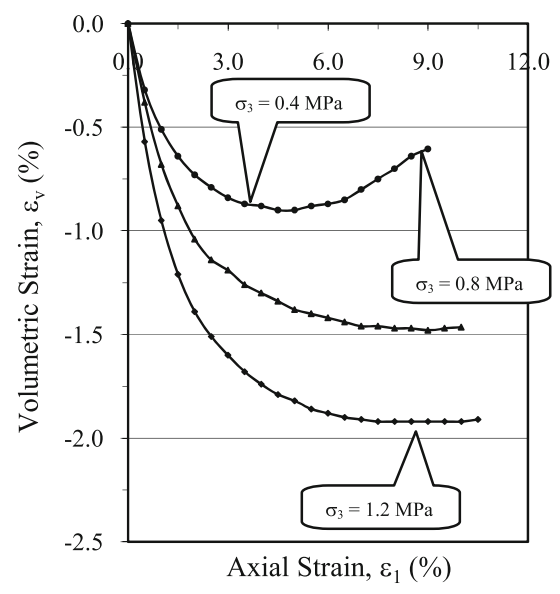

(b)

Fig. 8 Stress-Strain-Volume Change Behaviour of $80 \mathrm{~mm} \mathrm{~d}_{\max }$ for Renuka Dam Project Material. a Stress-strain behaviour b Volume change behaviour

particles (Venkatachalam 1993; Gupta 2000; Abbas 2003; Honkanadavar 2010, 2011, 2012a, 2012b). The effect of maximum particle size, $\mathrm{d}_{\max }$ on strength parameter, $\phi$ for both project materials are shown in the Fig. 13. It is observed that the angle of internal friction, $\phi$ increases with increase in $\mathrm{d}_{\max }$ for Renuka alluvial and $\phi$ decreases with increase in $d_{\max }$ for Salma dam quarried rockfill material. The values of angle of internal friction for Shah Nehar project (alluvial), Purulia dam (quarried) and Parbati dam project (quarried) rockfill materials reported by Abbas (2003) are also superimposed in Fig. 13. They show similar trend as that of Renuka riverbed and Salma quarried rockfill material. Due to higher interlocking of angular particles, the strength of quarried rockfill material is more than the rounded rockfill material for the same $d_{\text {max }}$.

\section{Constitutive Modeling}

Hierarchical single surface (HISS) model developed by Desai and co-workers (Desai and Siriwardhane 1980; Desai and Siriwardhane 1980; Desai et al. 1991) based on 


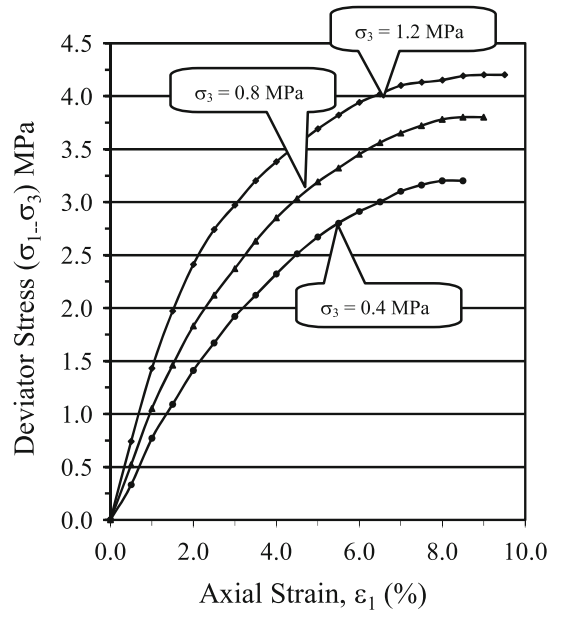

(a)

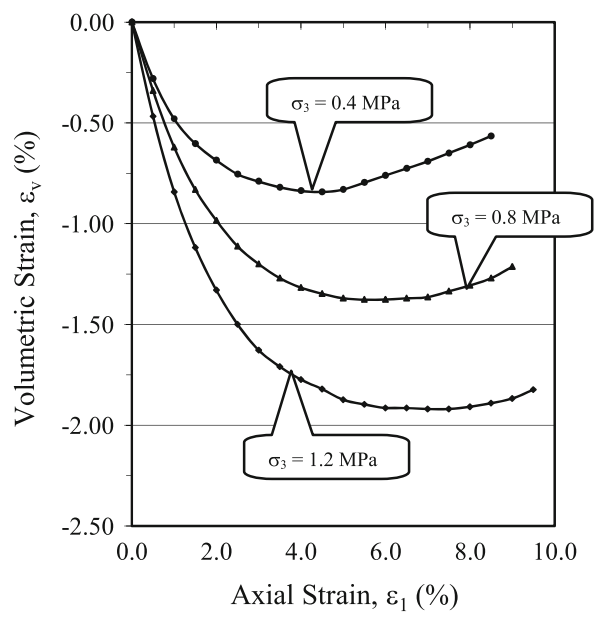

(b)

Fig. 9 Stress-Strain-Volume Change Behaviour of $25 \mathrm{~mm} \mathrm{~d}_{\max }$ for Salma Dam Project Material. a Stress-strain behaviour b Volume change behaviour

Fig. 10 Stress-StrainVolume Change Behaviour of $50 \mathrm{~mm} \mathrm{~d}_{\max }$ for Salma Dam Project Material. a Stress-strain behaviour b Volume change behaviour

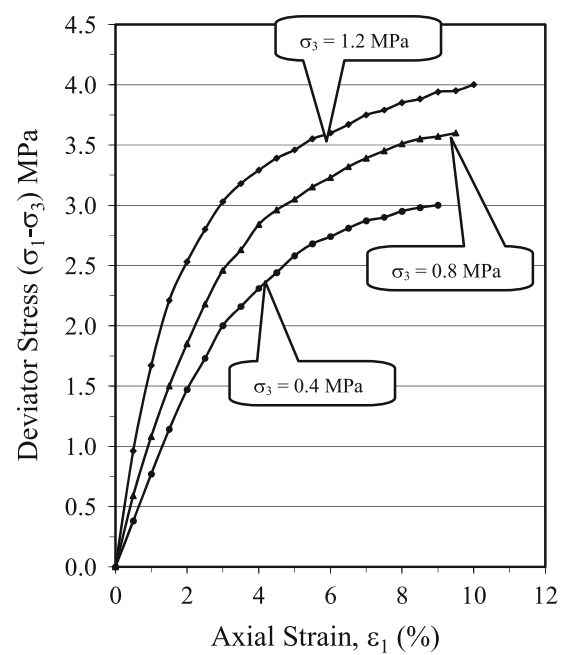

(a)

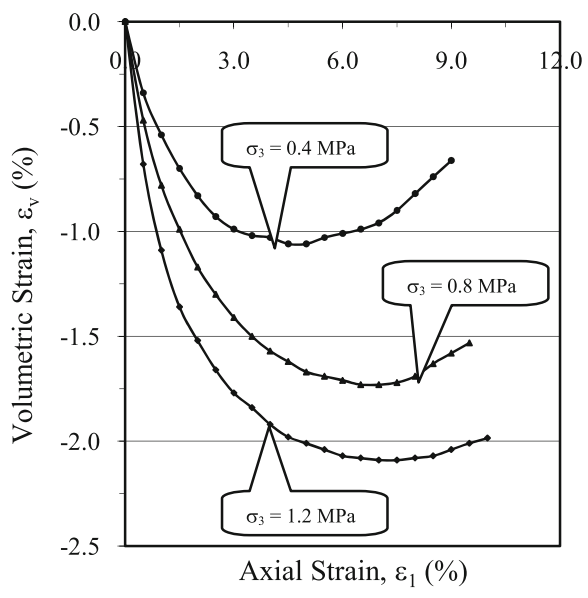

(b) elasto-plastic theory has been used to characterize the behavior of rockfill materials. The non-associative $\delta_{1}$ model (Desai and Wathugala 1987; Desai 2001; Varadarajan et al. 1999, 2003, 2006; Gupta 2000; Abbas 2003; Honkanadavar 2010; Honkanadavar and Sharma 2013) gives the plastic potential function as

$Q=\left[\frac{J_{2 D}}{P_{a}^{2}}\right]-\left[-\alpha_{Q}\left[\frac{J_{1}}{P_{a}}\right]^{n}+\gamma\left[\frac{J_{1}}{P_{a}}\right]^{2}\right]\left(1-\beta S_{r}\right)^{m}$

where,

$\alpha_{Q}=\alpha+\kappa\left(\alpha_{0}-\alpha\right)\left(1-r_{v}\right)$ in which $\kappa$ is non-associative parameter, $\alpha_{0}$ is $\alpha$ (hardening parameter) at the beginning of shear loading and

$r_{v}=\frac{\xi_{v}}{\xi}$

where, $\xi$ is plastic strain trajectory, and

$\xi_{v}=\int \frac{\left|d \varepsilon_{v}^{p}\right|}{\sqrt{3}}$

where, $d \varepsilon_{v}^{p}$ is the incremental plastic volumetric strain and $\xi_{\mathrm{v}}$ is volumetric part of $\xi$. 


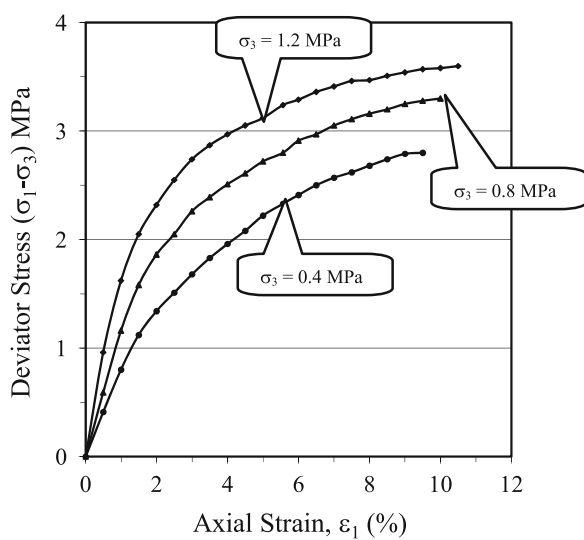

(a)

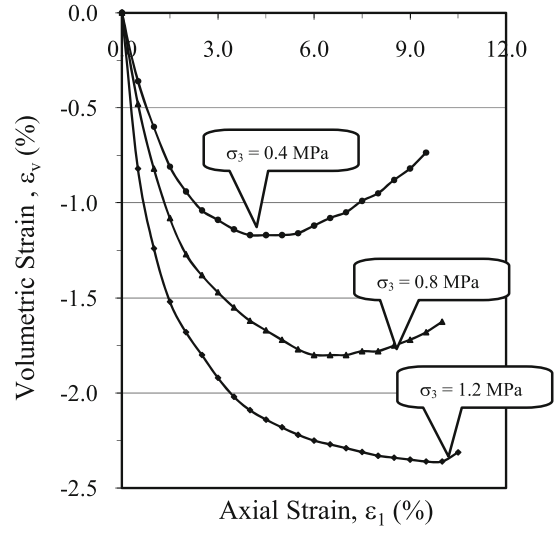

(b)

Fig. 11 Stress-Strain-Volume Change Behaviour of $80 \mathrm{~mm} \mathrm{~d}_{\max }$ for Salma Dam Project Material. a Stress-strain behaviour b Volume change behaviour

Fig. 12 Relation between Mean stress $\left(\sigma_{\mathrm{m}}\right) \mathrm{v} / \mathrm{s}$ deviator stress $\left(\sigma_{1}-\sigma_{3}\right)$ space for the $\mathrm{d}_{\max }$ of $25 \mathrm{~mm}$ of Renuka dam materials

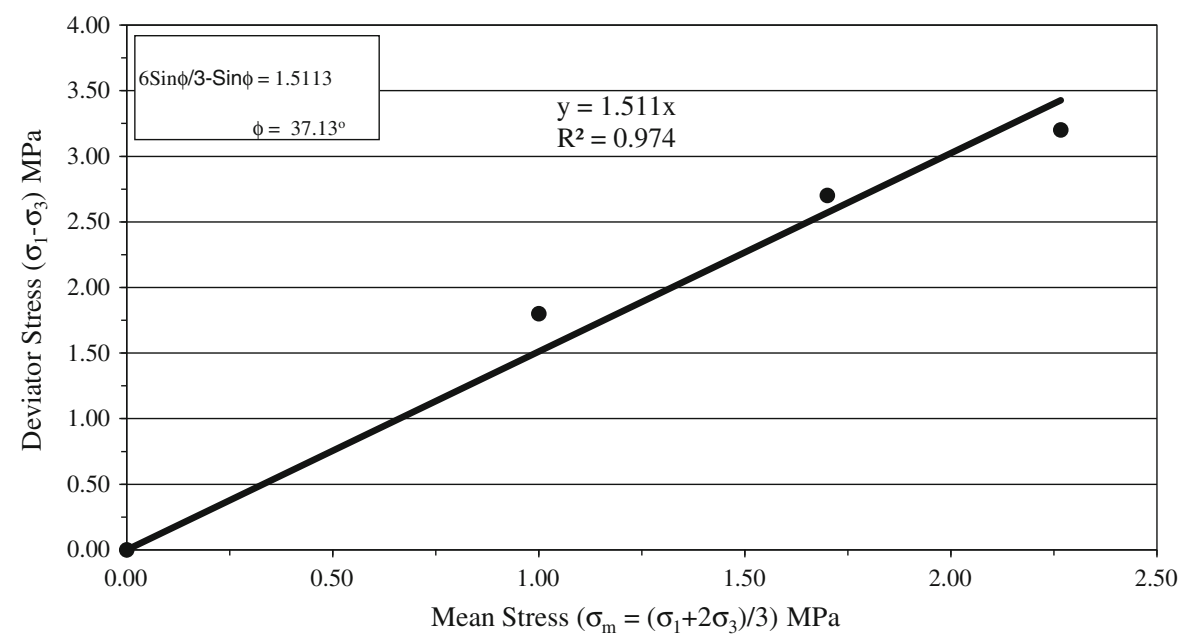

described in detail in various references (Varadarajan and Desai 1993; Gupta 2000; Desai 2001; Abbas 2003; Varadarajan et al. 2003, 2006; Honkanadavar 2010). The procedure is briefly presented herein.

\subsubsection{Elastic Parameters}

The elastic parameter, modulus of elasticity (initial modulus) of rockfill material, $\mathrm{E}$ is determined from the observed stress-strain response using the hyperbolic relationship (Kondner 1963),

$\left(\sigma_{1}-\sigma_{3}\right)=\frac{\varepsilon_{1}}{a+b \varepsilon_{1}}$

where, $\left(\sigma_{1}-\sigma_{3}\right)$ is deviator stress, $\varepsilon_{1}$ is axial strain, $a$ is constant (= inverse of modulus of elasticity, E)
The procedure for the determination of material parameters required in the HISS model has been 
Fig. 13 Variation of Angle of Internal Friction with Maximum Particle Size $\left(\mathrm{d}_{\max }\right)$

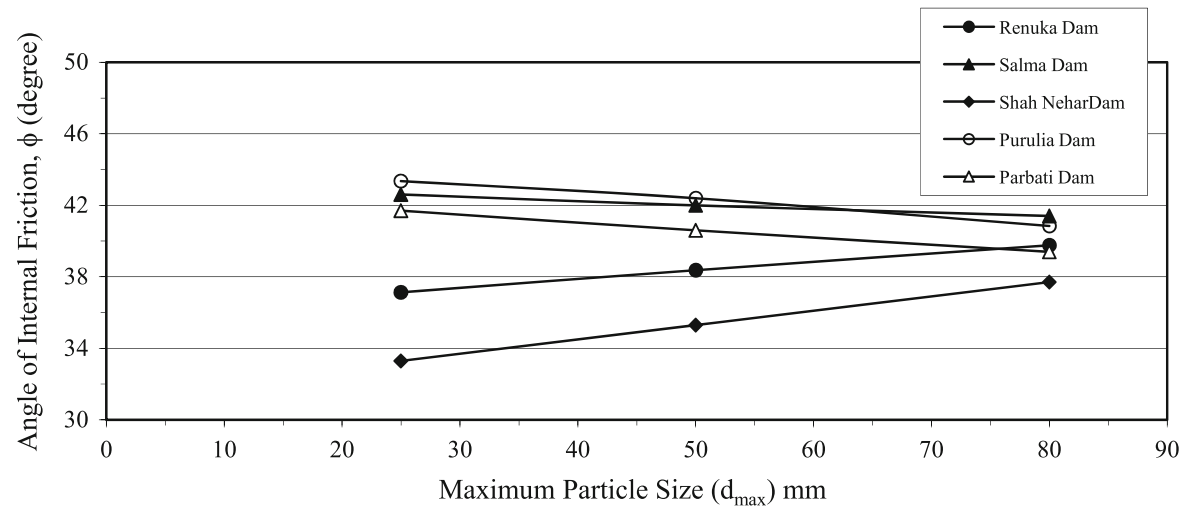

and $b$ is constant (= inverse of ultimate strength, $\left.\left(\sigma_{1}-\sigma_{3}\right)_{\text {ult }}\right)$. Equation (5) can be rewritten as

$\frac{\varepsilon_{1}}{\sigma_{1}-\sigma_{3}}=a+b \varepsilon_{1}$

The values of $\varepsilon_{1} /\left(\sigma_{1}-\sigma_{3}\right)$ are calculated from the initial part of the stress-strain curve and are plotted against $\varepsilon_{1}$. The intercept of the best fit line in the transformed plot is obtained as the value of the constant $a$. The reciprocal of the constant $a$ gives the modulus of elasticity of rockfill material, E.

The modulus of elasticity, $\mathrm{E}$ is expressed as a function of the confining pressure (Janbu 1963) as

$E=k P_{a}\left[\frac{\sigma_{3}}{P_{a}}\right]^{n^{\prime}}$

where, $\mathrm{k}$ and $n^{\prime}$ are the modulus number and modulus exponent of the material respectively, $\sigma_{3}$ is the confining pressure and $\mathrm{P}_{\mathrm{a}}$ is the atmospheric pressure. To determine the modulus number, $\mathrm{k}$ and modulus exponent, $n^{\prime}$, the plots between, $\mathrm{E} / \mathrm{P}_{\mathrm{a}}$ and $\sigma_{3} / \mathrm{P}_{\mathrm{a}}$ on $\log$ scale are made for all sizes of alluvial and quarried rockfill materials. The values of $\mathrm{k}$ and $n^{\prime}$ are determined as antilog of intercept on $\mathrm{y}$-axis and slope of a best fit line respectively. The lateral strain is determined from the initial part of axial strain v/s volumetric strain curve and then Poisson's ratio, $v$ is determined as the ratio of lateral strain to the axial strain.

\subsubsection{Ultimate Parameters}

For most of the geological materials $\mathrm{m}$ is found to be -0.5 (Desai et al. 1986). Therefore, in the present study, the value of $\mathrm{m}$ has been taken as -0.5 . The ultimate parameters $\gamma$ and $\beta$ can be related with angle of internal friction, $\phi$ (Desai 2001) as

$\beta=\frac{1-p^{2 / m}}{1+p^{2 / m}}$

where,

$p=\frac{\tan \theta_{C}}{\tan \theta_{E}}$

$\tan \theta_{C}=\left[\sqrt{\gamma(1-\beta)^{m}}\right]_{C}=\frac{2}{\sqrt{3}}\left[\frac{\sin \varphi_{C}}{3-\sin \varphi_{C}}\right]$

$\tan \theta_{E}=\left[\sqrt{\gamma(1+\beta)}^{m}\right]_{E}=\frac{2}{\sqrt{3}}\left[\frac{\sin \varphi_{E}}{3+\sin \varphi_{E}}\right]$

In the present analysis, triaxial compression tests are conducted and friction angle in compression $\left(\varphi_{C}\right)$ has been determined for all the $\mathrm{d}_{\max }$ of alluvial and quarried modeled rockfill materials. The friction angle in extension $\left(\varphi_{E}\right)$ is assumed equal to the friction angle in compression i.e. $\varphi_{C}=\varphi_{E}$ (Gupta 2000; Abbas 2003; Honkanadavar 2010). First, $\beta$ is determined from Eq. (8) and then $\gamma$ is computed using Eq. (10) or (11) for the alluvial and quarried modeled rockfill materials tested.

\subsubsection{Phase Change Parameter}

The phase change parameter, $\mathrm{n}$ is related to the state of stress at which the material starts dilating. Therefore, the point at which dilation starts is corresponding to $d \varepsilon_{v}^{p}=0$ and therefore, the phase change parameter, $\mathrm{n}$ can be determined as 
Table 5 Material Parameters for HISS Model

\begin{tabular}{|c|c|c|c|c|c|c|c|c|c|c|}
\hline \multirow[t]{2}{*}{ Rockfill Materials } & \multirow[t]{2}{*}{$\mathrm{d}_{\max }(\mathrm{mm})$} & \multicolumn{3}{|c|}{ Elasticity } & \multicolumn{2}{|c|}{ Ultimate } & \multirow{2}{*}{$\begin{array}{l}\text { Phase Change } \\
n\end{array}$} & \multicolumn{2}{|l|}{ Hardening } & \multirow{2}{*}{$\begin{array}{l}\text { Non-associative } \\
\kappa\end{array}$} \\
\hline & & $\mathrm{k}$ & $n^{\prime}$ & $v$ & $\gamma$ & $\beta$ & & $\mathrm{a}_{1}$ & $\eta_{1}$ & \\
\hline \multirow[t]{3}{*}{ Renuka Dam } & 25 & 374.36 & 0.466 & 0.32 & 0.063 & 0.72 & 3.0 & $6.5 \times 10^{-6}$ & 1.00 & 0.236 \\
\hline & 50 & 385.21 & 0.469 & 0.31 & 0.067 & 0.72 & 3.0 & $6.0 \times 10^{-6}$ & 1.05 & 0.235 \\
\hline & 80 & 410.677 & 0.4624 & 0.30 & 0.072 & 0.72 & 3.0 & $5.5 \times 10^{-6}$ & 1.07 & 0.226 \\
\hline \multirow[t]{3}{*}{ Salma Dam } & 25 & 289.201 & 0.528 & 0.31 & 0.061 & 0.72 & 3.0 & $5.0 \times 10^{-6}$ & 0.93 & 0.240 \\
\hline & 50 & 318.85 & 0.515 & 0.3 & 0.066 & 0.72 & 3.0 & $3.5 \times 10^{-6}$ & 0.97 & 0.239 \\
\hline & 80 & 346.019 & 0.5082 & 0.28 & 0.071 & 0.72 & 3.0 & $2.0 \times 10^{-6}$ & 1.03 & 0.238 \\
\hline
\end{tabular}
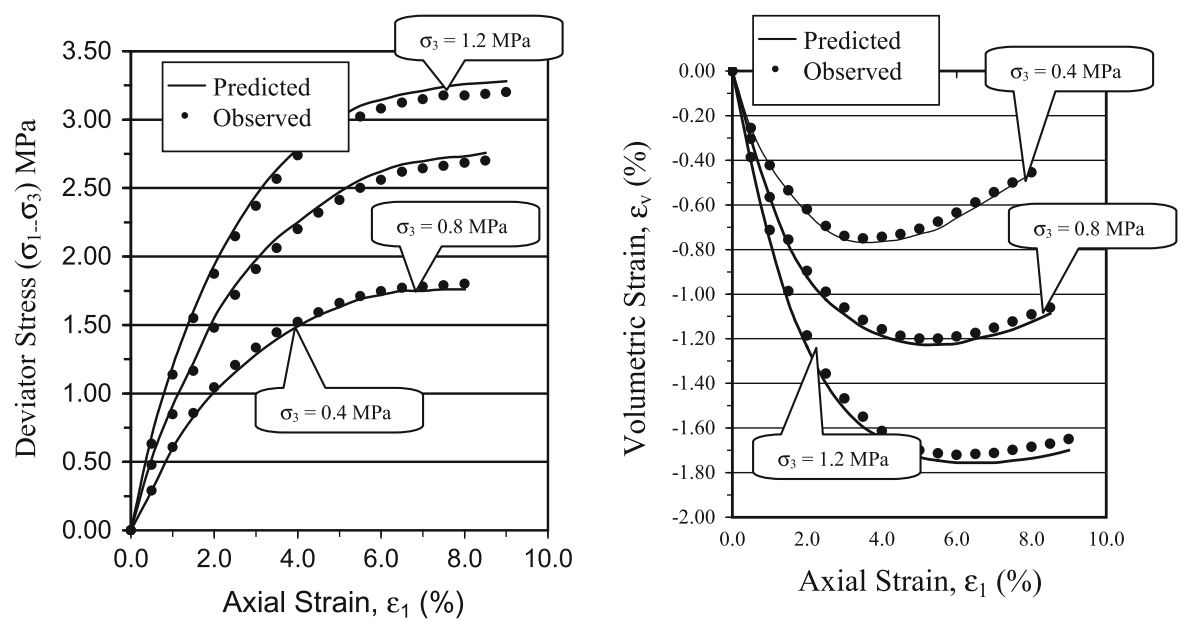

Fig. 14 Observed and Predicted Stress-Strain-Volume Change Behaviour of $25 \mathrm{~mm} \mathrm{~d}_{\max }$ for Renuka Dam Project Material

$n=\frac{2}{\left[1-\left[\frac{J_{2 D}}{J_{1}^{2}}\right]\right] \frac{1}{F_{S} \gamma}}$

where, $J_{1}$ is first invariant of stress tensor, $J_{2 D}$ is the second invariant of deviator stress tensor, $F_{s}$ is shape function and $\gamma$ is the ultimate parameter. The point at which $d \varepsilon_{v}^{p}=0$ is determined and $\mathrm{n}$ is calculated using Eq. (12). An average of all $\mathrm{n}$ values for different tests conducted for a $d_{\max }$ is taken as overall value of $n$ for that size of rockfill material. Similarly, $n$ value is calculated for all the $\mathrm{d}_{\max }$ of alluvial and quarried modeled rockfill materials.

\subsubsection{Hardening Parameters}

In the present study, $\alpha$ is assumed as the function of $\xi$ as

$\alpha=\frac{a_{1}}{\xi_{1}^{\eta}}$
Taking natural $\log$ on both sides of Eq. (13) gives,

$\ln (\alpha)=\ln \left(a_{1}\right)-\eta_{1} \ln (\xi)$

A plot $\alpha \mathrm{v} / \mathrm{s} \xi$ is drawn on logarithmic scale to get $\mathrm{a}_{1}$ and $\eta_{1}$ as antilog of intercept and slope respectively of the best fit line. The hardening parameters for all the $\mathrm{d}_{\max }$ of alluvial and quarried modeled rockfill materials were computed.

\subsubsection{Non-associative Parameter}

The non-associative parameter, $\kappa$ in Eq. (2) is determined based on the following equation:

$\left(\frac{d \varepsilon_{v}^{p}}{d \varepsilon_{11}^{p}}\right)=\frac{\left(3 \frac{\partial Q}{\partial J_{1}}\right)}{\frac{\partial Q}{\partial \sigma_{11}}}$

where, $d \varepsilon_{11}^{p}=$ axial plastic strain increment; $\sigma_{11}=$ axial stress, and $d \varepsilon_{v}^{p}=$ volumetric plastic strain increment. The ratio of $d \varepsilon_{v}^{p} / d \varepsilon_{11}^{p}$ can be obtained from 

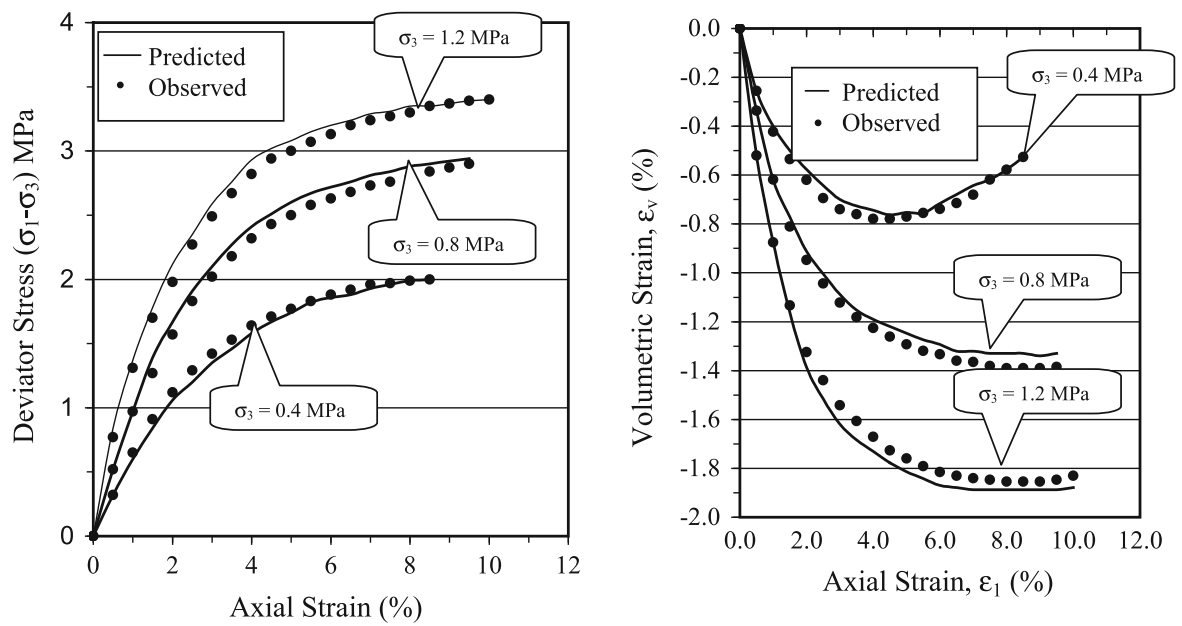

Fig. 15 Observed and Predicted Stress-Strain-Volume Change Behaviour of $50 \mathrm{~mm} \mathrm{~d}_{\max }$ for Renuka Dam Project Material

Fig. 16 Observed and Predicted Stress-StrainVolume Change Behaviour of $80 \mathrm{~mm} \mathrm{~d}_{\max }$ for Renuka Dam Project Material

Fig. 17 Observed and Predicted Stress-StrainVolume Change Behaviour of $25 \mathrm{~mm} \mathrm{~d}_{\max }$ for Salma Dam Project Material
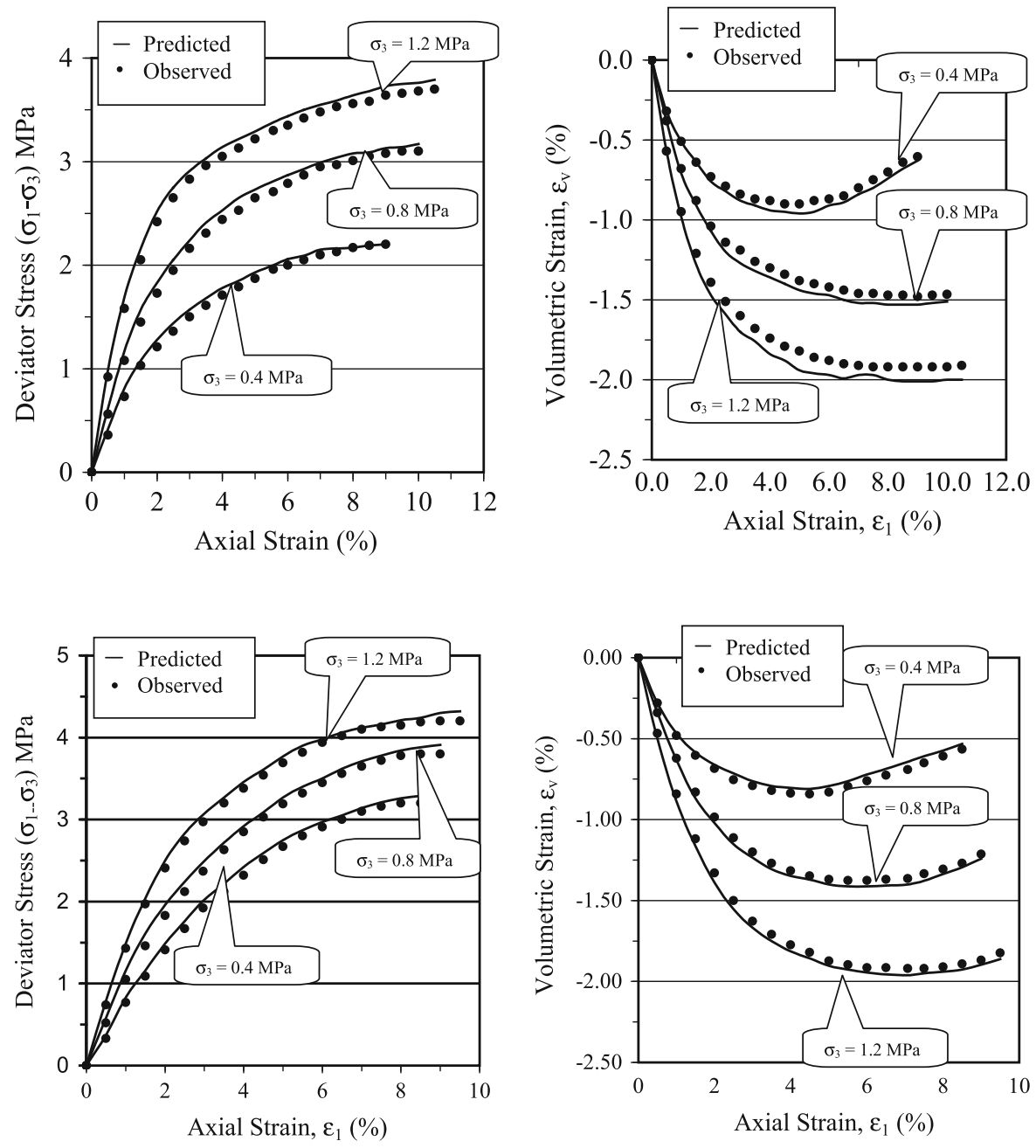
Fig. 18 Observed and Predicted Stress-StrainVolume Change Behaviour of $50 \mathrm{~mm} \mathrm{~d}_{\max }$ for Salma Dam Project Material
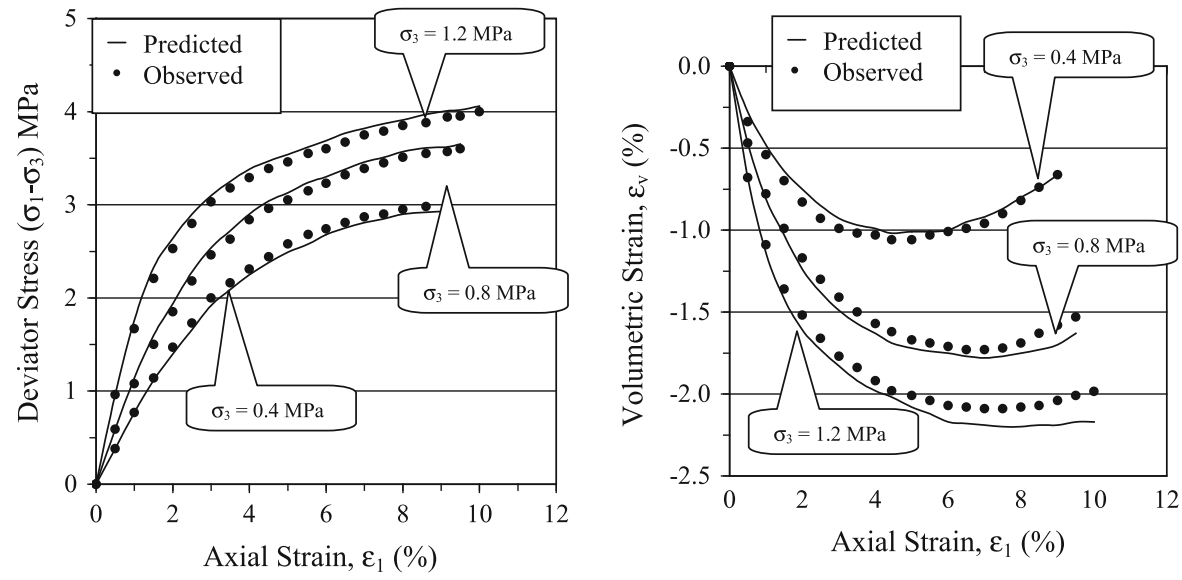
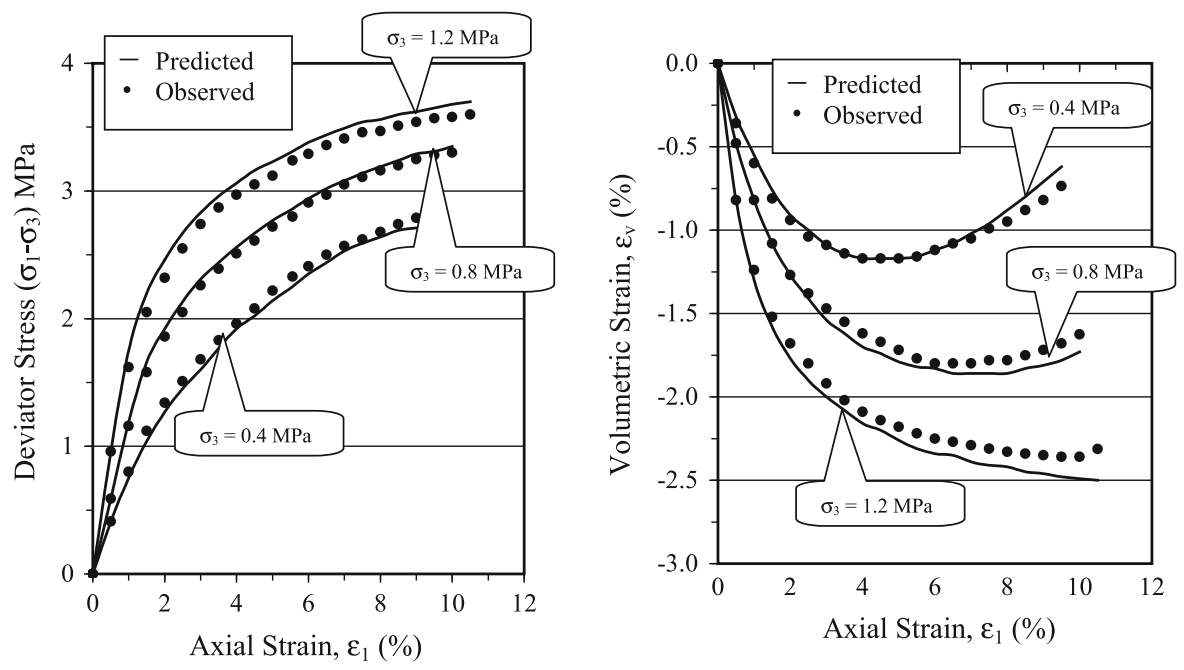

Fig. 19 Observed and Predicted Stress-Strain-Volume Change Behaviour of $80 \mathrm{~mm} \mathrm{~d}$ max for Salma Dam Project Material

the slope of the observed $d \varepsilon_{11}^{p} \mathrm{v} / \mathrm{s} d \varepsilon_{v}^{p}$ response by choosing a point in the ultimate state. The value of $\alpha_{\mathrm{Q}}$ [from Eq. (2)] which is represented on the righthand side of Eq. (16) can then be found as the left-hand side is now known. Using this value along with $\alpha$ and $r_{v}$ at ultimate condition, the average value of $\kappa$ is determined.

Following the above mentioned procedure, material parameters for both Renuka dam alluvial and Salma dam quarried rockfill materials have been determined and are presented in the Table 5. Using the determined material parameters, stress-strain-volume change behaviour for all the $d_{\max }$ tested with different $\sigma_{3}$ is predicted using HISS model. The predicted behaviour is compared with the observed behaviour from the laboratory triaxial shear tests. From the comparison, it is observed that both results match closely. The observed and predicted stress-strain-volume change behaviour for both projects rockfill material is shown in Figs. 14, 15, 16, 17, 18 and 19.

\section{Conclusions}

Two types of modeled rockfill materials viz. alluvial from Renuka dam, India and blasted quarried from Salma dam, Afghanistan were collected and consolidated drained triaxial tests were conducted. Stressstrain-volume change behaviour for all the $d_{\max }$ were studied. It is observed that the stress-strain behaviour 
is non-linear, inelastic and stress level dependent for all the $d_{\max }$ of both project materials. The deviator stress and the axial strain at failure increases with increase in confining pressure for all the tested materials. It is also observed that the effect of $\sigma_{3}$ is same on both types of material. From the volume change behaviour, it is observed that the volume decreases during the initial shearing and with further shearing material experiences dilation effect. This dilation effect reduces with increase in $\sigma_{3}$ and $\mathrm{d}_{\max }$ for both projects material. The shear strength parameter, angle of internal friction $(\phi)$ increases with increase in $\mathrm{d}_{\max }$ for alluvial rockfill material and reverse trend is observed for blasted quarried rockfill material.

Rockfill materials have been characterised by using heirarchical single surface (HISS) model based on elasto-plasticity. Stress-strain-volume change behaviour has ben predicted for all the $\mathrm{d}_{\max }$ of both alluvial and quarried rockfill materials. The predicted and observed (laboratory test results) stress-strain-volume change results were compared. From the comparison, it is observed that both results match closely. Hence, it is suggested that the HISS model can be used successfully to characterise both alluvial and blasted quarried rockfill materials.

Acknowledgments Authors would like to thank the staff of rockfill division, CSMRS for their help during the testing. Thanks to the project authorities of Renuka dam and Salma dam for providing the modeled rockfill materials for carrying out this research work.

Open Access This article is distributed under the terms of the Creative Commons Attribution License which permits any use, distribution, and reproduction in any medium, provided the original author(s) and the source are credited.

\section{References}

Abbas SM (2003) Testing and Modeling the Behaviour of Riverbed and Quarried Rockfill Materials, Ph. D. Thesis, I.I.T. Delhi

Desai CS (2001) Mechanics of materials and interfaces-the disturbed state concept. CRC Press, Florida

Desai CS, Siriwardhane HJ (1980) A concept for correction function to account for non-associative characteristics of geologic media. Int $\mathbf{J}$ Numer Anal Methods Geomech 4:377-387

Desai CS, Ugai K (1996) Application of non-associative model for geologic materials for active earth pressure experiment. Int J Rock Mech Min Sci 33(2):88A
Desai CS, Somasundaram S, Frantziskonis G (1986) A hierarchical approach for constitutive modelling of geologic materials. Int $\mathrm{J}$ Numer Anal Methods Geomech 10:225-257

Desai CS, Sharma KG, Wathugala GW, Rigby DB (1991) Implementation of hierarchical single surface $\delta 0$ and $\delta 1$, models in finite element procedure. Int $\mathrm{J}$ Numer Anal Methods Geomech 15:649-680

Desai CS, Samtani NC, Vulliet L (1995a) Constitutive modeling and analysis of creep slopes. Int J Rock Mech Min Sci 32(8):403A-404A

Desai CS, Samtani NC, Vulliet L (1995b) Constitutive modeling and analysis of creep slopes. J Geotech Eng, ASCE $121: 43-56$

Gupta AK (2000) Constitutive Modeling of Rockfill Material, Ph.D. Thesis, I.I.T. Delhi

Honkanadavar NP (2010), Testing and Modeling the Behaviour of Modeled and Prototype Rockfill Materials, Ph.D. Thesis, I.I.T.Delhi

Honkanadavar NP, Sharma KG (2011), Prediction of shear strength parameter for prototype quarried rockfill materials using index properties, Indian Geotechnical Conference, IGC-2011, Kochi

Honkanadavar NP, Sharma KG (2012a), Testing and modeling the behaviour of alluvial rockfill material. Indian Geotech Conf, IGC-2012, Vol-II, pp 131-134

Honkanadavar NP, Sharma KG (2013)"Testing and modeling the behaviour of riverbed and quarried rockfill materials. Accepted for publication in International Journal of Geomechanics, ASCE

Honkanadavar NP, Gupta SL, Ratnam M (2012) Effect of particle size and confining pressure on shear strength parameter of rockfill materials. Int $\mathbf{J}$ Adv Civil Eng Archit I(I):49-63

Kondner, R.L. (1963), "Hyperbolic stress-strain response, cohesive soils, J SMFE, ASCE, 89, SM1, pp 115-143

Lowe J (1964) Shear strength of coarse embankment dam materials. Congr Large Dams 3:745-761

Marachi ND, Chan CK, Seed HB Duncan JM (1969), Strength and Deformation Characteristics of Rockfill Materials, Report No. TE 69(5), Civil Engineering Department, University of California, Berkeley, USA

Marsal RJ (1967) Large Scale Testing of Rockfill Materials. J Soil Mech Found Div ASCE 93(2):27-43

Najjar YM, Zaman MM, Tabbaa R (1994) Constitutive modelling of sand: a comparative study. In:Proceedings of the eight international conference on computer methods and advances in geomechanics, Morgantown, West Virginia, May 22-28, 1994, pp 641-646

Varadarajan A, Desai CS (1987) A constitutive model for drained behaviour of jamuna sand. Indian Geotech J 1(14):272-290

Varadarajan A, Desai CS (1993) Material constants of a constitutive model determination and use. Indian Geotech $\mathbf{J}$ 23(3):291-313

Varadarajan A, Sharma KG Abbas SM (2006) Constitutive model for rockfill materials and determination of material constants. Int J Geomech @ ASCE/July/August 2006. pp 226-237

Varadarajan A, Sharma KG Soni KM (1994) Modelling of reinforced sand using hierarchical model. Proc 8th Int Conf 
Comput Methods Adv in Geo-Mech, pp 707-712

Varadarajan A, Sharma KG, Venkatachalam K, Gupta AK (1997) Constitutive modelling of a rockfill material using HISS model. Proc IGC-97 Vadodara 1:153-156

Varadarajan A, Sharma KG, Venkatachalam K, Gupta AK (1999) Constitutive modelling of rockfill materials, Proc Fourth Int Conf Const Laws Eng Mater. Rensselaer Polytechnic Institute, Troy

Varadarajan A, Sharma KG, Venkatachalam K, Abbas SM (2002a) Constitutive modeling of rockfill materials from tehri dam, Uttaranchal. Proc. IGC2002 Allahabad, India 1:592-595

Varadarajan A, Sharma KG, Abbas SM, Venkatachalam K (2002b), "Testing and Modeling the Behaviour of Two Rockfill Materials, J Geotech Geoenv Eng, ASCE, June (2003). pp 206-218
Varadarajan A, Sharma KG, Venkatachalam K, Gupta AK (2003) "Testing and modeling two rockfill materials. J Geotech Geoenv Eng ASCE 129(3):206-218

Venkatachalam K (1993) Prediction of mechanical behaviour of rockfill materials, Ph.D. Thesis, I.I.T. Delhi

Xiao Y, Liu HL, Zhu JG, Shi WC (2011a) Dilatancy equation of rockfill material under the tru triaxial stress condition. Sci China Tech Sci 54(S1):175-184

Xiao Y, Liu HL, Zhu JG, Shi WC (2011b) Modeling and behaviours of rockfill materials in three-dimensional stress space. Sci China Tech Sci 55(10):2877-2892

Xiao Y, Liu HL, Zhu JG, Shi WC (2012) A 3D bounding surface model for rockfill materials. Sci China Tech Sci 54(11):2904-2915 